\title{
Generation and Utilization of Microbial Biomass Hydrolysates in Recovery and Production of Poly(3-hydroxybutyrate)
}

Jian Yu, Michael Porter and Matt Jaremko

Additional information is available at the end of the chapter

http://dx.doi.org/10.5772/52940

\section{Introduction}

In moving towards sustainable manufacturing with reduced carbon footprint, bio-based fuels, chemicals and materials produced from renewable resources have attracted great interest. Microbial cells, in working with other chemical and enzymatic catalysts, are often used in the conversion of feedstocks to desired products, involving different species of bacteria, yeast, filamentous fungi, and microalgae. A substantial amount of microbial biomass is generated in the industrial fermentations and often discarded as a waste. Because of a high cost associated with growth and disposal of the cell mass, reusing the microbial biomass may be an attractive alternative to waste disposal. In contrast to the biomass as energy storage (e.g. starch and oil) or plant structure (e.g. cellulose and hemi-cellulose), microbial biomass is biologically active, consisting primarily of proteins (10-60 wt \%), nucleic acid (1-30 wt\%), and lipids (1-15\%) [1]. Few cases of reusing microbial biomass exist in industrial processes.

Poly(3-hydroxybutyrate) (PHB) is a representative polyhydroxyalkanoate (PHA) that is formed by many bacterial species as carbon and energy reserve [2,3]. Although the biopolyesters made from renewable feedstocks have the potential of replacing petroleumbased thermoplastics in many environmentally friendly applications, they are not widely accepted in the markets because of the high production cost [4]. Extensive research has been conducted to use cheap feedstocks [5,6], develop high cell density fermentation technology for high PHA productivity [7,8], and improve microbial strains that exhibit good performance under high osmotic pressure and environmental stress [9-11]. One major cost factor of PHA production is the recovery and purification of biopolyester for desired purity and material properties [4,12]. Depending on strains and culture conditions, biopolyester may account for $50-80 \mathrm{wt} \%$ of cell mass [13]. They are stored in microbial cells as tiny 
amorphous granules [0.2-0.5 $\mu \mathrm{m}$ in diameter] and need a sophisticated treatment to separate them from the residual cell mass [14-16]. Two technologies, based-on solvent extraction or biomass dissolution, are usually adopted in PHA recovery. With solvent extraction, the PHA granules are dissolved in appropriate organic solvents, leaving cells or residual biomass intact $[17,18]$. With cell mass dissolution, the PHA granules are left intact while the non-PHA cell mass is decomposed and dissolved in aqueous solutions with help of biological and/or chemical agents $[19,20]$. Following either treatment, PHA and non-PHA cell mass can be separated with conventional solid/liquid separations. Separating biopolyester from the cells would generate a substantial amount of residual microbial biomass, 0.25 to $1 \mathrm{~kg}$ dry mass per $\mathrm{kg}$ of PHA resin, depending on the initial PHA content. As a mixture of proteins, nucleic acids, lipids, and wall fragments, the residual biomass has no market value and is discarded at an extra disposal cost.

According to the microbial structure and cellular composition [1], the residual microbial biomass is actually consisting of true biological compounds formed during cell growth while PHA is just a carbon storage material. In a conventional PHA fermentation, sufficient substrates and nutrients $(\mathrm{C}, \mathrm{N}, \mathrm{P}$, minerals and some organic growth factors) are supplied to grow enough cell mass that in turn or simultaneously synthesize biopolyester from carbon substrates. A large portion of organic carbons and nutrients are therefore consumed to generate new cell mass that is going to be discarded as a solid waste after polymer recovery. Ideally, the residual biomass should be reused by microbial cells to generate new cell mass and/or PHA polymers. This would not only reduce the cost of waste treatment and disposal, but also save the cost of nutrients in PHA fermentation. The bacterial cells, however, cannot assimilate their cell mass because they lack appropriate enzymes to break down various biological macromolecules and their complex structure such as cellular walls and membranes [19]. If the cells or mutants from genetic engineering could easily assimilate their structural components, they might not be suitable to industrial PHA production because the cells would undergo autolysis under high environmental stress. It is highly possible, however, to make the residual biomass reusable during PHA recovery in which the non-PHA cell mass is decomposed and hydrolyzed in aqueous solutions [20]. Integration of PHA recovery with reusing of residual biomass in microbial PHA fermentation is a novel and challenging technology. This work shows the generation of biomass hydrolysates in a downstream PHB recovery and the beneficial utilization of the hydrolysates in cell growth and PHB formation.

\section{Materials and methods}

\subsection{Microbial cultures}

A laboratory strain of Ralstonia eutropha maintained on agar slant was used in this work. The agar medium contained (per liter): $5 \mathrm{~g}$ yeast extract, $5 \mathrm{~g}$ peptone, $2.5 \mathrm{~g}$ meat extract and $15 \mathrm{~g}$ agar. A 16S RNA analysis indicates that the strain has $100 \%$ alignment with Ralstonia eutropha H16. The cells were cultivated in $200 \mathrm{~mL}$ mineral medium containing: $160 \mathrm{~mL}$ glucose mineral solution, $8 \mathrm{~mL}$ inoculum, 5-20 mL solutions of residual microbial biomass 
hydrolysates, and the rest pre-sterilized water. The glucose mineral solution contained (per liter): 12 g glucose, $2 \mathrm{~g} \mathrm{NaH}_{2} \mathrm{PO}_{4}, 2.8 \mathrm{~g} \mathrm{~K}_{2} \mathrm{HPO}_{4}, 0.5 \mathrm{~g} \mathrm{MgSO}_{4} .7 \mathrm{H}_{2} \mathrm{O}, 1 \mathrm{~g}\left(\mathrm{NH}_{4}\right)_{2} \mathrm{SO}_{4}$ and $1 \mathrm{~mL}$ trace solution [21]. The culture solution was shaken in a $500 \mathrm{~mL}$ baffled flask at $30{ }^{\circ} \mathrm{C}$ and $200 \mathrm{rpm}$ in a rotary incubator for 24 or 48 hours. Cell mass was harvested from $50 \mathrm{~mL}$ medium with centrifugation at 5,000 $\mathrm{g}$ for $10 \mathrm{~min}$ and freeze dried for measurement of cell mass concentration and PHB content.

A large amount of PHB-containing cell mass for biopolyester recovery was produced with a fed-batch culture in a 3L bench-top bioreactor (BioFlo 110, New Brunswick Scientific Co. $\mathrm{NJ})$. The temperature, $\mathrm{pH}$ and dissolved oxygen were controlled at $30{ }^{\circ} \mathrm{C}, 6.8$, and $10 \%$ air situation, respectively. A feed solution prepared with a sugar manufacturing byproduct containing about $50 \%$ sucrose was introduced into the bioreactor till the cell density reached $130 \mathrm{~g} / \mathrm{L}$ and PHB concentration $94 \mathrm{~g} / \mathrm{L}$ (72\% PHB of cell mass). The cell mass was harvested with centrifugation and re-suspended in an acidic water $\left(0.2 \mathrm{M} \mathrm{H}_{2} \mathrm{SO}_{4}\right)$ to make a cell slurry of $278 \mathrm{~g}$ dry mass/L. The slurry was reserved for later use.

\subsection{PHB recovery}

The biopolyester was recovered and purified by dissolving the non-PHA cell mass (28\% $\mathrm{w} / \mathrm{w}$ ) in sequential treatments consisting of acid pretreatment, base treatment, hypochlorite whitening, washing and drying [22].

Acid pretreatment: The cell mass in acidic solution was heated to boil and maintained for one hour under ambient conditions. The pretreated cellular solids were cooled to room temperature and separated from acid solution with centrifugation at 5,000 $\mathrm{g}$ for $10 \mathrm{~min}$. The dissolved microbial biomass in the supernatant solution is referred to acid hydrolysates. The insoluble wet pellets were subjected to next base treatment.

Base treatment: The insoluble solids from the acid pretreatment were re-suspended in an equivalent volume of water to form slurry of about $200 \mathrm{~g} \mathrm{DM} / \mathrm{L}$. The solution $\mathrm{pH}$ was raised to 10 to 11 with $5 \mathrm{M} \mathrm{NaOH}$ solution and stirred under ambient conditions for 30 to $60 \mathrm{~min}$. A small amount of surfactants such as sodium dodecylsulfate (SDS, $\mathrm{CH}_{3}\left(\mathrm{CH}_{2}\right){ }_{11} \mathrm{OSO}_{3} \mathrm{Na}$ ) might be added to a concentration of 5 to $10 \mathrm{~g} / \mathrm{L}$. The slurry was then heated to boiling and maintained for $10 \mathrm{~min}$ under ambient conditions. After centrifugation, the dissolved biomass in the supernatant solution is referred to base hydrolysates. The sequential acid and base treatments above could also be performed without separation of the acid hydrolysates. In this case, sodium hydroxide was directly added into the acidic cell slurry and the $\mathrm{pH}$ was raised to 10-11 for base treatment. After centrifugation, the supernatant solution contained the hydrolysates generated from both acid and base treatments and is refereed to acid-base hydrolysates.

Whitening and washing: The insoluble wet pellets from base treatment were re-suspended in a commercially available bleaching solution containing $6 \% \mathrm{w} / \mathrm{w}$ of hypochlorite. The slurry was stirred for 1 to 2 hours under ambient conditions. The white PHB pellets were recovered with centrifugation. A small amount of biomass was dissolved and mineralized in 
the bleaching solution because of chemical oxidation, which is not considered for reuse in this work. The wet PHA pellets were washed two times with water and dried in oven. The final PHB product is a white powder.

\subsection{Chemical and material analysis}

The dissolution of non-PHA cell mass was monitored by measuring the characteristic absorption of amino acid residues at $280 \mathrm{~nm}$ with a UV/VIS spectrophotometer (Beckman Coulter DU530, Fullerton, CA). The concentration of proteins that can be stained in Bradford assay was measured with the spectrophotometer after protein-dye binding [23]. The content of PHB in original cell mass, in sequential treatments, and final product were determined via methanolysis of the biopolyester in methanol ( $3 \mathrm{wt} \%$ sulfuric acid) at $100{ }^{\circ} \mathrm{C}$ for $8-10$ hours [24]. The 3-hydroxybutyric methyl ester was hydrolyzed into 3-hydroxybutyric acid when the solution $\mathrm{pH}$ was raised to 11 with a $10 \mathrm{~N} \mathrm{NaOH}$ solution. The liquid samples were analyzed using an HPLC equipped with a UV detector (Shimadzu, Japan) and an organic acid column (OA-1000, Alltech, Deerfield, IL). The column was maintained at $65{ }^{\circ} \mathrm{C}$ and eluted with a water-sulfuric acid solution $(\mathrm{pH} 2)$ at $0.8 \mathrm{~mL} / \mathrm{min}$. The monomeric acid and crotonic acid, a trace byproduct formed in methanolysis, were detected at $210 \mathrm{~nm}$. For data quality control, the biopolyester was also extracted from the freeze-dried cell mass in hot chloroform followed by precipitation with methanol [21]. The PHB content was calculated from the purified PHB and compared with the results of HPLC analysis.

The purified PHB and non-PHB cell mass were examined with a Nicolet Avatar 370 FTIR spectrometer (Thermo Electron Co., Madison, WI). The solids were pressed on a germanium crystal window of micro-horizontal attenuated total reflectance (ATR) for measurement of single-reflection and absorption of infrared radiation by the specimens. The thermal properties of PHB powder were examined with a differential scanning calorimeter (DSC). A Modulated 2920 instrument (TA Instruments, New Castle, DE) equipped with a refrigerated cooling system was run in heat-cool-heat mode at a rate of 5 ${ }^{\circ} \mathrm{C} /$ min under nitrogen. The selected temperature range was $30^{\circ} \mathrm{C}-210{ }^{\circ} \mathrm{C}$ with sample weights of 4.5 - 5.5 mgs. Images of cell and PHB granules were obtained with an energyfiltering transmission electron microscopy (120 kV LEO 912, Carl Zeiss SMT Inc. MA). The instrument has an in-column electron energy loss spectrometer, allowing analysis of light element in thin sections.

\section{Results and discussion}

\subsection{Sequential treatment for PHB recovery}

Figure 1 elucidates the sequential treatment of PHB-containing cells in a process of PHB recovery and purification. Starting with 100 dry cell mass, the cells in a slurry of $278 \mathrm{~g} \mathrm{DM} / \mathrm{L}$ were first treated in an acidic solution $\left(0.2 \mathrm{M} \mathrm{H}_{2} \mathrm{SO}_{4}\right)$. A substantial amount of microbial proteins was released from the damaged cells, depending on temperature and time as shown in Figure 2. 


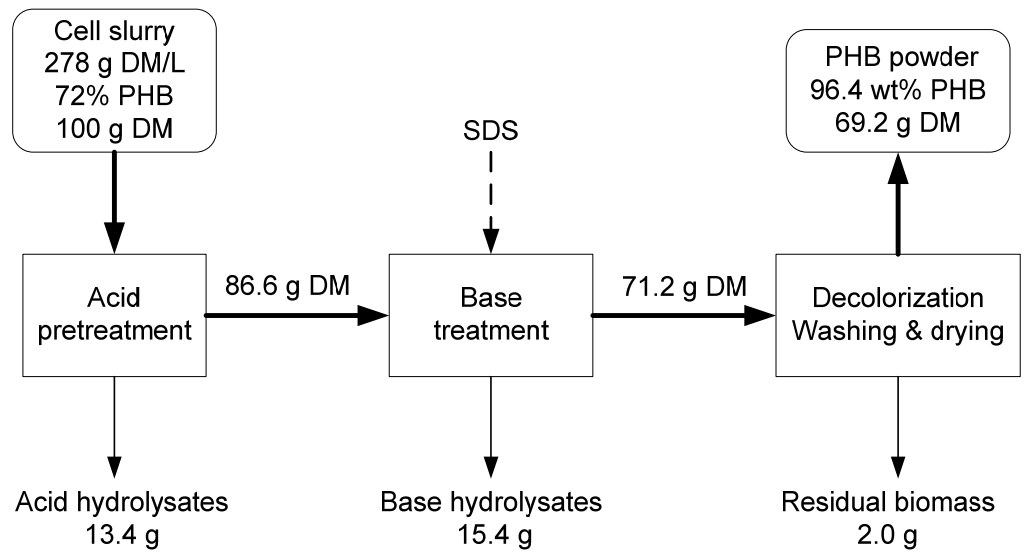

Figure 1. Sequential treatment of PHB-containing biomass (100 g dry mass) and generation of biomass hydrolysates. Surfactant SDS is optional for high PHB purity.

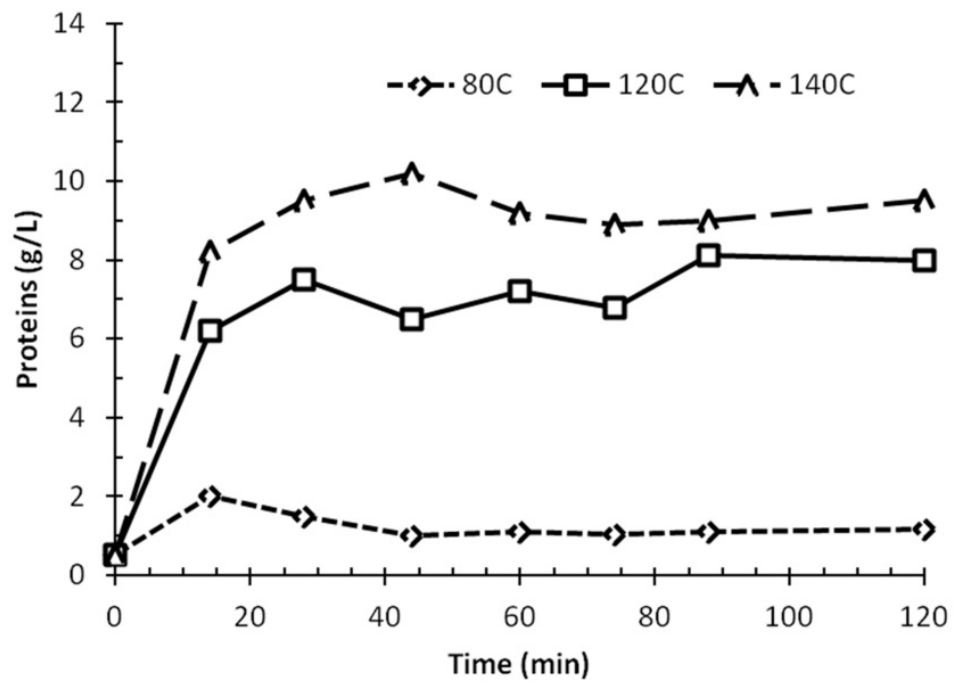

Figure 2. Effect of temperature and time on release of proteins from microbial cells in acidic solution.

During the acid pretreatment, the original amorphous PHB granules became partially crystallized (data not shown here), which improved the granule's resistance to abiotic degradation in the following treatments [20]. The biomass hydrolysates (13.4 g dry mass) dissolved in supernatant solution was discharged as acid hydrolysates. The residual PHBcontaining biomass was further subjected to a base treatment by raising the slurry $\mathrm{pH}$ to 10.5 with a $10 \mathrm{M} \mathrm{NaOH}$ solution. About $15.4 \mathrm{~g}$ dry mass was dissolved in the supernatant solution and discharged as base hydrolysates. After a small amount of residual biomass $(2 \mathrm{~g}$ dry mass) was removed via oxidation with hypochlorite, the final PHB powder $(69.2 \mathrm{~g}$ dry mass) contained $96.4 \mathrm{wt} \%$ PHB. The overall PHB recovery yield was $92.6 \%$, or $7-8 \%$ PHB 
was lost in repeated hydrolysis and solid/liquid separations. When a small amount of surfactant such as sodium dodecylsulfate (SDS) was added in the base treatment, the PHB purity of the final biopolyester resin could be increased to $99.4 \%$.
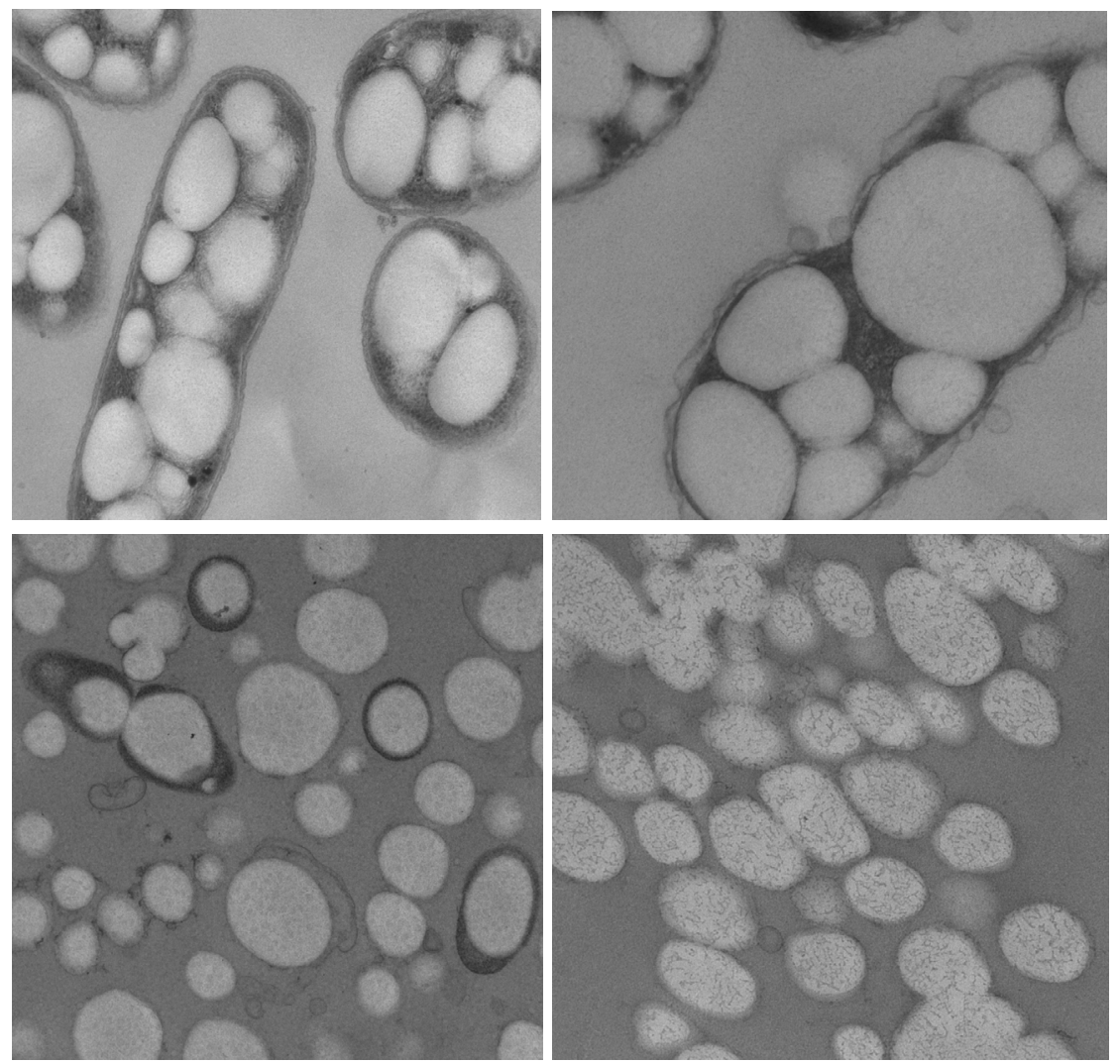

Figure 3. Transmission electron microscope images: microbial cells containing native PHB granules (top left), cells with damaged walls in acid pretreatment (top right), PHB granules with attached residual cell mass (bottom left), and purified PHB granules (bottom right)

Figure 3 is the electronic microscopy images of the original cells with PHB inclusion bodies, the cells with damaged porous cell walls in acid pretreatment, the PHB granules with residual cellular mass in base treatment, and the purified PHB granules after whitening and washing. It is interesting to see that the cell walls became porous in the acid pretreatment, which allowed release of proteins and other biological components in cytoplasm. The original cell structure, however, was maintained to keep the PHB granules within the damaged cells. After base treatment, the cell walls were almost completely decomposed, and a small amount of residual cell mass, probably some hydrophobic cellular components, was attached to PHB granules. After whitening and washing, the non-PHA cell mass was removed to give purified $\mathrm{PHB}$ granules. 


\subsection{Purified PHB versus original cell mass}

Figure 4 compares the FTIR spectra of the purified PHB granules and the original oven-dried PHB-containing cell mass. The peaks of amide I band at $\sim 1650 \mathrm{~cm}^{-1}$ and amide II band at $\sim 1540$ $\mathrm{cm}^{-1}$ (N-H bend) are characteristic infrared radiation absorption of the proteins in cell mass $[25,26]$. They disappeared in the spectrum of purified PHB granules. This was confirmed with a pure PHB prepared with solvent extraction (the spectrum not shown here). It was also noticed that the native amorphous PHB granules became crystallized during the process of purification, which will be further discussed. This structural change in PHB matrix was also reflected in the absorption of infrared radiation at wave numbers of 1180,1210 , and $1280 \mathrm{~nm}^{-1}$ [27].

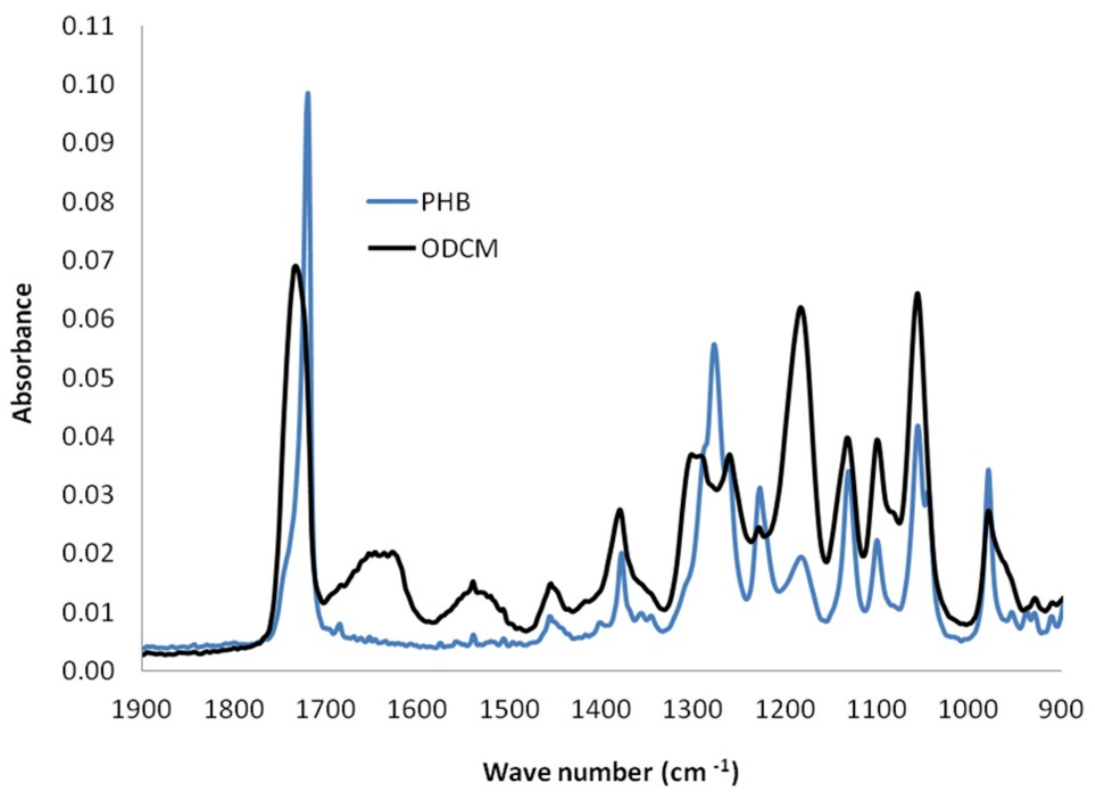

Figure 4. FTIR spectra of purified PHB granules and PHB-containing oven-dried cell mass (ODCM).

The purified PHB granules were subjected to repeated heating and cooling in a differential scanning calorimeter (DSC), and the results are presented in Figure 5. In the first heating (solid blue line), two melting peaks were observed, around $156^{\circ} \mathrm{C}$ and $167{ }^{\circ} \mathrm{C}$, respectively, indicating that the PHB powder had two types of crystalline structures. The melted polymer was re-crystallized again during the first cooling (dotted blue line), starting at $100{ }^{\circ} \mathrm{C}$ and ending at $80{ }^{\circ} \mathrm{C}$. When the crystallized PHB was subjected to the second heating (solid black line), it was noticed that the relatively small melting peak at $156^{\circ} \mathrm{C}$ (or crystalline structure) observed in the first heating disappeared. Only one melting peak (crystalline structure) was observed, starting at $160{ }^{\circ} \mathrm{C}$ and ending at $181{ }^{\circ} \mathrm{C}$ with a peak around $174{ }^{\circ} \mathrm{C}$. This phenomenon indicates that the first melting peak in the first heating represents a type of crystalline structure that could not be formed at a cooling rate of $5{ }^{\circ} \mathrm{C} / \mathrm{min}$. The whole endothermic event in the second heating absorbed 87J/g PHB. Based on a theoretical melting 
enthalpy of $100 \%$ crystalline PHB (146 J/g) [28], it can be estimated that about $60 \%$ of PHB matrix was crystallized during the first cooling (Eq. 1).

$$
X_{C}=\frac{\Delta H_{m}}{\Delta H_{t}}=\frac{87}{146} \approx 60 \%
$$

Where $\mathrm{X}_{\mathrm{c}}$ is the PHB crystallinity, $\Delta \mathrm{H}_{\mathrm{m}}$ and $\Delta \mathrm{H}_{\mathrm{t}}$ are the melting enthalpies of PHB powder and a theoretical PHB crystal [28].

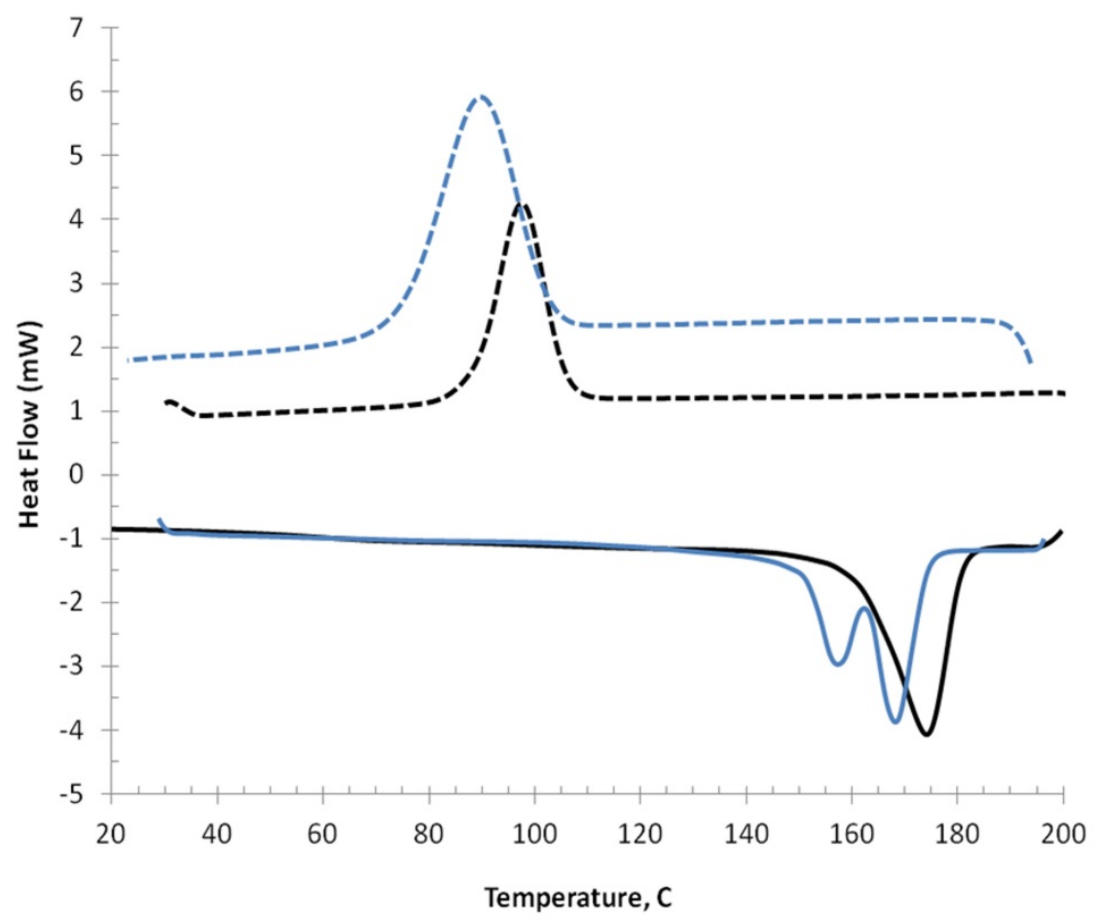

Figure 5. Differential scanning calorimetry (DSC) measurement of purified PHB granules in repeated heating and cooling: the first heating (solid blue line) followed by the first cooling (dotted blue line) and the second heating (solid black line) following by the second cooling (dotted black line).

In contrast to the thermal plastic behavior of PHB powders, the oven-dried cell mass containing 73\% PHB could not be melted till carbonization. This fact reveals a complicated interaction between the biopolyester and the residual biomass. It also shows that a composite of $73 \%$ PHB and $27 \%$ cellular mass is not a thermoplastic material, but a rigid composite. The role of cellular mass in the PHB composite is not clear yet.

\subsection{Cell debris solutions}

As shown in Figure 1, about $94 \mathrm{wt} \%$ of residual microbial biomass was decomposed and hydrolyzed in the acid pretreatment ( $44 \%$ biomass) and base treatment ( $50 \%$ biomass). The remaining small amount ( $\sim 6 \mathrm{wt} \%)$ of residual cell mass is most likely mineralized via 
oxidation with hypochlorite, a strong oxidation agent. The acid hydrolysates are primarily the cytoplasm proteins released from the damaged cells (Figures 2 and 3). The released biological macromolecules were subjected to further hydrolysis in the thermal acidic solution. The acid hydrolysates solution had a clean brownish color and contained 30-45 g/ of soluble biomass, depending on the density of cell slurry and treatment conditions. The base hydrolysates solution with a dark color contained the hydrolysis products of hydrophobic cell components including lipids and membrane proteins. After centrifugation, the concentration of soluble biomass in the supernatant solution was 30 to $50 \mathrm{~g} / \mathrm{L}$. The sequential treatments disrupted and dissolved the structural components so that they could be removed from PHB granules. Equally important, the biomass and biological macromolecules were decomposed into small molecule hydrolysates such as amino acids and organic acids. These hydrolysates could become appropriate substrates that can be assimilated by microbial cells in microbial PHB production.

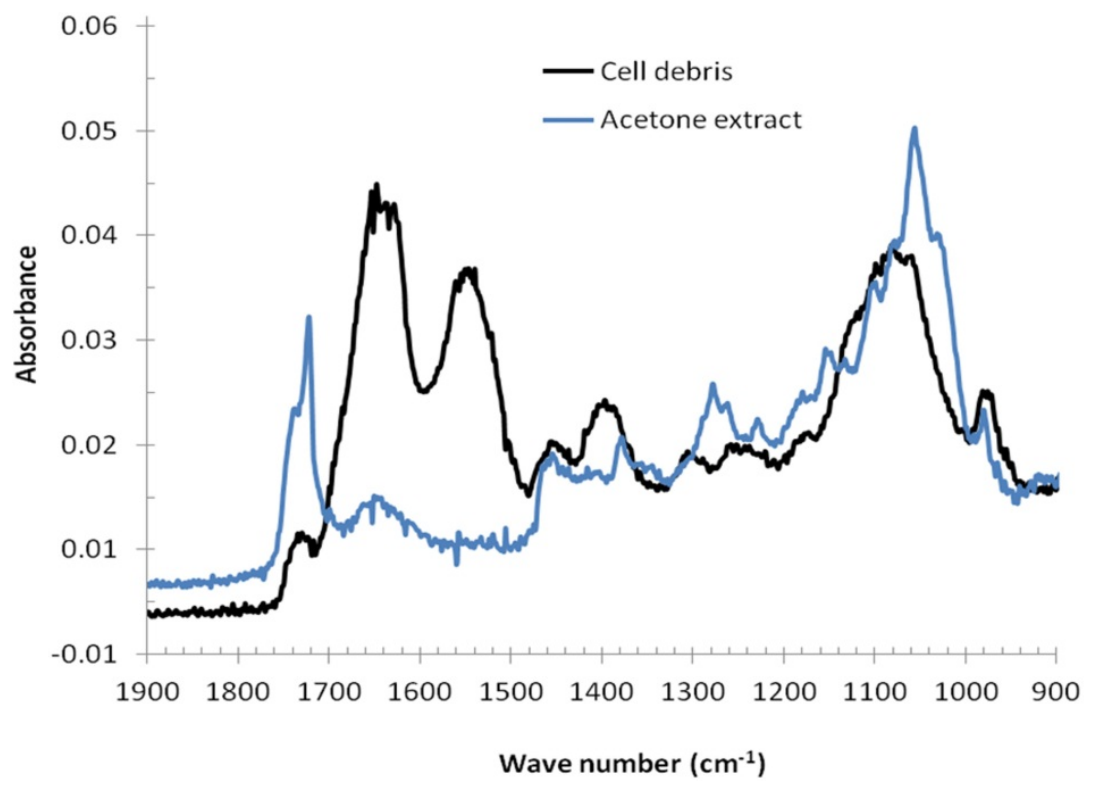

Figure 6. FTIR spectra of acid-base biomass hydrolysates (black line, cell debris) and cellular components extracted with acetone (blue line)

In addition to the two types of biomass hydrolysates described above, a mixed hydrolysates of residual biomass was generated when the acid pretreatment and base treatment were performed sequentially without solid/liquid separation. It eliminated one operation of solid/liquid separation, but the acid hydrolysates (primarily proteins) were subjected to additional hydrolysis in the base solution. Figure 6 shows the FTIR spectrum of an acid-base hydrolysates. As observed in the IR spectrum of the original cell mass in Figure 4, a major component of the hydrolysates was the amino acids or proteins with infrared radiation absorbance at 1500 to $1700 \mathrm{~cm}^{-1}$ [25]. Another major component in the acid/base hydrolysates had the IR absorbance at 1000 to $1200 \mathrm{~cm}^{-1}$, which was attributed to cell lipids 
and/or similar compounds. This was confirmed with the spectrum of cell mass extract in acetone. Acetone is a common solvent used to remove hydrophobic lipids, steroids and pigments from PHB-containing cell mass [17]. It does not dissolve and extract PHB and proteins. Based on the observations above, it was concluded that the major cellular components in the acid hydrolysates were derived from cytoplasm proteins and in the base hydrolysates from cell walls, lipids and membrane proteins. In the acid-base hydrolysates, the products were derived from both groups, i.e. amino acids or peptides derived from proteins, and lipids derived from cell walls and membranes. It should be pointed out that the composition of acid-base hydrolysates is not a simple mixture of acid- and basehydrolysates because the acid hydrolysates were further hydrolyzed in base treatment.

Because of the hydrophobic properties of PHB granules, the residual hydrophobic impurities of cell mass might be attached to the granules and difficult to remove by washing with water. A surfactant such as SDS in the base treatment can remove most of the impurities to a high PHB purity $(>99 \% \mathrm{w} / \mathrm{w})$. A large portion of the surfactant, however, may be left in the hydrolysates solution and may have an adverse effect on the reuse of the hydrolysates in PHB production.

\subsection{Utilization of acid hydrolysates in PHB biosynthesis}

An acid hydrolysates solution containing $38 \mathrm{~g} / \mathrm{L}$ of soluble solids was added into a glucose medium to give a predetermined percentage of residual biomass to glucose at $0,10,20$ and $25 \%$ of sugar, respectively. The initial glucose concentration was controlled at a constant level of $9.6 \mathrm{~g} / \mathrm{L}$. The flask cultures of no biomass hydrolysates were run in parallel as controls. As shown in Figure 7, the acid biomass hydrolysates were beneficial to both cell growth and PHA formation. Because the residual biomass might also contain some insoluble solids and PHB granules lost in PHB recovery, both cell density and PHB concentration were compared at 24 hours and 48 hours to show the net gains. The benefits of biomass hydrolysates were statistically significant based on the deviations of duplicates.

The acid hydrolysates might have two positive effects on microbial PHA formation. First, the hydrolysates promoted cell activity on glucose utilization, giving higher cell densities than the controls in the first 24 hours. This nutritional effect was similar to those of organic nutrients such as yeast extract and peptone, which are widely used in microbial cultures to provide nutrients and growth factors to the cells. A fast cell growth can reduce the cultivation time, resulting in a high PHB productivity. Second, the biomass hydrolysates might also be used as an extra carbon source to generate more cell mass than the controls in 48 hours. This carbon source effect, however, might play a minor role because the cell density did not increase with cell debris load. In fact, too much acid hydrolysates deteriorated the gains as shown in Figure 7. The reason is not clear yet. A load of acid biomass hydrolysates to glucose from 10 to $20 \mathrm{wt} \%$ seems appropriate for both cell growth and PHB formation.

\subsection{Utilization of acid-base biomass hydrolysates}

An acid-base biomass hydrolysates solution containing $48.5 \mathrm{~g} / \mathrm{L}$ of soluble solids was added into a glucose medium at predetermined percentage of cell debris to glucose from 0 to $40 \%$. The glucose medium without biomass hydrolysates was run in parallel as controls. As shown 

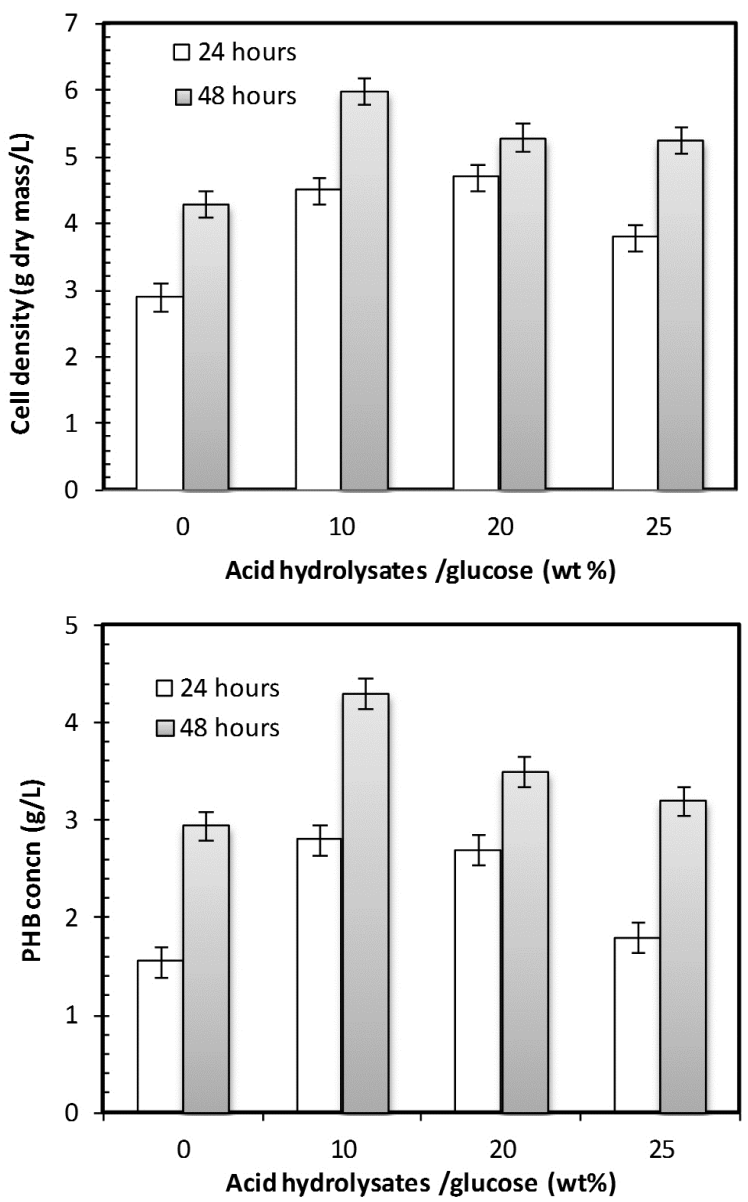

Figure 7. Effect of acid hydrolysates to glucose loading ratio on cell growth (top) and PHB formation (bottom) in reuse of the residual biomass for PHB production.

in Table 1, the concentrations of both cell mass and PHA content, after 48 hours cultivation, were substantially higher than those of the control. The overall cell growth yield $(\mathrm{Yx} / \mathrm{s})$ and PHA formation yield (Yp/s) are calculated from the amounts of cell mass and PHA formed in 48 hours based on the initial concentration of glucose. The relative yields ( $\mathrm{Yx}^{\prime}$ and $\left.\mathrm{Yp}^{\prime}\right)$ based on the controls were increased by $100-300 \%$. More interestingly, the inhibitory effect of acid biomass hydrolysates was not observed in the use of acid-base hydrolysates, and the load of cell debris to glucose can be increased to about $39 \mathrm{wt} \%$. Most likely, the unknown inhibitors in acid hydrolysates were further decomposed into less inhibitory hydrolysates in the base treatment. Since the acid biomass hydrolysates contained primarily the cytoplasm proteins released from the damaged cells, the soluble proteins might adversely affect cell growth at high concentrations. After being hydrolyzed in base solution into peptides and amino acids, the small molecule hydrolysates become less inhibitory and more usable to the cells. 


\begin{tabular}{|c|c|c|c|c|c|c|c|}
\hline $\begin{array}{c}\text { Biomass } \\
\text { hydrolysates } \\
(\mathrm{g} / \mathrm{L})\end{array}$ & $\begin{array}{c}\text { Biomass } \\
/ \text { Glucose } \\
(\mathrm{wt} \%)\end{array}$ & $\begin{array}{c}\text { Cell } \\
\text { density } \\
(\mathrm{g} / \mathrm{L})\end{array}$ & $\begin{array}{c}\text { PHB } \\
(\mathrm{wt} \%)\end{array}$ & $\mathrm{Yx} / \mathrm{s}$ & $\mathrm{Yp} / \mathrm{s}$ & $\mathrm{Yx} \mathrm{x}^{\prime}$ & $\mathrm{Y} / \mathrm{g} \mathrm{p}^{\prime}$ \\
\hline 0.0 & 0 & $2.1 \pm 0.5$ & $45 \pm 1.2$ & 0.18 & 0.081 & 1.0 & 1.0 \\
\hline 1.15 & 9.4 & $4.0 \pm 0.2$ & $55 \pm 1.6$ & 0.33 & 0.18 & 1.8 & 2.24 \\
\hline 2.30 & 18.8 & $4.5 \pm 0.3$ & $60 \pm 1.7$ & 0.38 & 0.23 & 2.1 & 2.84 \\
\hline 4.60 & 38.8 & $5.6 \pm 0.4$ & $61 \pm 1.5$ & 0.47 & 0.29 & 2.6 & 3.58 \\
\hline
\end{tabular}

Note: the flask cultures were maintained at $30{ }^{\circ} \mathrm{C}$ and $200 \mathrm{rpm}$ in a rotary incubator for 48 hours. The yields of cell mass (Yx/s) and PHB (Yp/s) were based on the initial glucose concentration. The relative yields $\left(\mathrm{Yx}^{\prime}\right.$ and $\left.\mathrm{Yp}^{\prime}\right)$ are the ratios of yields with hydrolysates to the control without hydrolsyates.

Table 1. Effect of acid-base biomass hydrolysates on cell growth and PHB formation

\subsection{Comparison of three types of cell debris}

In the process of PHB recovery (Figure 1), three types of biomass hydrolysates may be generated, depending on operations: acid, base, and acid-base biomass hydrolysates. They may have different nutrient values or inhibitory effects on cell growth and PHB synthesis. Solutions of three types of biomass hydrolysates were added into a glucose medium for predetermined concentrations of cell debris. Controls without hydrolysates were run in parallel. The ratios of cell densities $(\mathrm{g} / \mathrm{L})$ to the controls were compared after 48 hours cultivation as shown in Figure 8. The nutritional value of acid hydrolysates in cell growth is similar to that of base hydrolysates. The nutrient value of acid-base hydrolysates, however, is significantly higher than those of hydrolysates from individual treatment.

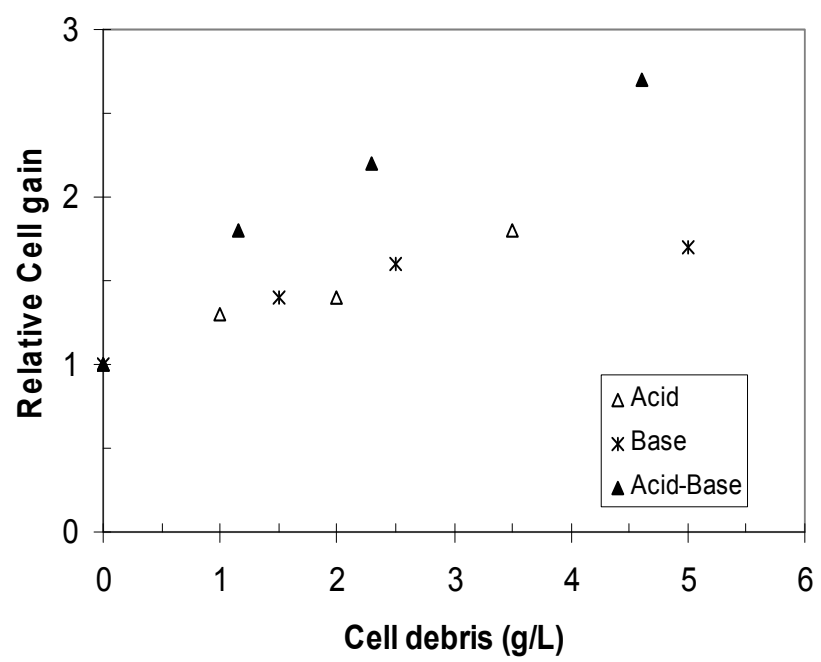

Figure 8. Comparison of three types of biomass hydrolysates (acid, base, and acid-base) on cell growth in a glucose mineral medium. The relative cell gain is the ratio of cell density to the controls.

Based on an average cell yield $(\mathrm{Yx} / \mathrm{s}=0.45)$ of PHB fermentation on glucose [29], $45 \mathrm{~kg}$ of cell mass containing $70 \mathrm{wt} \%$ of $\mathrm{PHB}$ is generated from $100 \mathrm{~kg}$ of glucose consumed. A 
downstream recovery and purification as shown in Figure 1 can generate $31 \mathrm{~kg}$ PHB resin and $13 \mathrm{~kg}$ acid-base hydrolysis of residual microbial biomass. It is assumed that the acid hydrolysates are not separated, but hydrolyzed sequentially in the base treatment and discharged with the base hydrolysates together. If this amount of residual biomass is reused in next PHB fermentation, the percentage of biomass hydrolysates to glucose is $13 \%$ at maximum (13 kg for $100 \mathrm{~kg}$ glucose), a moderate load of biomass hydrolysates (Table 1). In real fermentations, more glucose is often added because of the residual glucose in the spent medium. This quick calculation indicates that most of residual biomass discharged from downstream separations can be reused in the next PHA fermentation. In addition to the elimination of a waste stream, the productivity and yields of PHA fermentation can also be significantly improved.

\subsection{Effect of SDS in biomass hydrolysates solution}

SDS is a popular surfactant used in PHA recovery to disrupt the cells or remove a small amount of hydrophobic impurities from PHB granules [30, 31]. The purity of PHB granules can be increased from $96.4 \%$ to above $99 \%$ when a small amount of SDS was added in the base treatment. The surfactant left in the base solution, however, may have an adverse effect when the cell debris is reused in microbial PHB fermentation. An acid-base biomass hydrolysates solution containing $48.5 \mathrm{~g} / \mathrm{L}$ of soluble solids and SDS were added into a glucose medium. The cell debris concentration was kept at $1.94 \mathrm{~g} / \mathrm{L}$, and SDS concentration was increased from 0.2 to $0.8 \mathrm{~g} / \mathrm{L}$ with SDS. Controls without biomass hydrolysates and SDS were run in parallel. Table 2 gives the results of cell growth and PHA formation at different surfactant levels at 24 and 48 hours, respectively.

\begin{tabular}{|c|c|c|c|c|c|}
\hline $\begin{array}{c}\text { Biomass } \\
\text { hydrolysates } \\
(\mathrm{g} / \mathrm{L})\end{array}$ & \multirow{2}{*}{$\begin{array}{c}\text { SDS } \\
(\mathrm{g} / \mathrm{L})\end{array}$} & \multicolumn{2}{|c|}{24 hours } & \multicolumn{2}{c|}{48 hours } \\
\cline { 3 - 6 } & & $\begin{array}{c}\text { Cell mass } \\
(\mathrm{g} / \mathrm{L})\end{array}$ & $\begin{array}{c}\text { PHB } \\
(\mathrm{wt} \%)\end{array}$ & $\begin{array}{c}\text { Cell mass } \\
(\mathrm{g} / \mathrm{L})\end{array}$ & $\begin{array}{c}\text { PHB } \\
(\mathrm{wt} \%)\end{array}$ \\
\hline 0 & 0 & $2.08 \pm 0.02$ & $36.8 \pm 1.1$ & $2.7 \pm 0.02$ & $44.4 \pm 0.6$ \\
\hline 1.94 & 0.2 & $3.69 \pm 0.06$ & $49.7 \pm 2.1$ & $4.99 \pm 0.04$ & $60.6 \pm 1.1$ \\
\hline 1.94 & 0.4 & $3.27 \pm 0.05$ & $39.6 \pm 1.2$ & $4.58 \pm 0.04$ & $53.8 \pm 0.8$ \\
\hline 1.94 & 0.6 & $2.70 \pm 0.04$ & $33.9 \pm 1.5$ & $3.51 \pm 0.03$ & $50.3 \pm 0.7$ \\
\hline 1.94 & 0.8 & $2.59 \pm 0.04$ & $17.8 \pm 1.3$ & $3.54 \pm 0.03$ & $25.8 \pm 1.2$ \\
\hline
\end{tabular}

Note: flask cultures were maintained at $30^{\circ} \mathrm{C}$ and $200 \mathrm{rpm}$ in a rotary incubator.

Table 2. Effect of surfactant SDS and biomass hydrolysates on cell growth and PHB formation

Compared with the controls of no biomass hydrolysates and surfactant, all the cultures containing the acid-base hydrolysates exhibited better cell growth. Particularly, the increase of cell concentration from 24 hours to 48 hours was the new cell mass formed in 24 hours from glucose and cell debris in the presence of SDS. The formation of PHB, however, was deteriorated at high SDS concentrations $(0.6-0.8 \mathrm{~g} / \mathrm{L})$. At a low or moderate SDS concentrations $(0.2-0.4 \mathrm{~g} / \mathrm{L})$, the positive effect from biomass hydrolysates was much higher than the negative effect of surfactant. The PHB concentrations, after 48 hours cultivation, 
were 2.4 to $3 \mathrm{~g} / \mathrm{l}$, in comparison with $1.2 \mathrm{~g} / \mathrm{L}$ of the control. The results in Table 2 indicate that the dosage of SDS in PHA recovery should be controlled according to the amount of residual microbial biomass generated. The mass ratio of SDS to biomass hydrolysates should be less than $20 \% \mathrm{w} / \mathrm{w}$ or better at $10 \% \mathrm{w} / \mathrm{w}$. In a typical PHB recovery process as shown in Figure 1, the amount of SDS used should be less than $2.9 \mathrm{~g}$ for $10 \%$ of acid-base cell debris or $5.8 \mathrm{~g}$ for $20 \%$ of acid-base cell debris. The consumption of SDS is therefore $4-8 \%$ of PHB resin produced. It is much lower than the SDS dosages used in the conventional separations [30, 31].

\section{Conclusion}

Residual microbial biomass is an inevitable waste generated in downstream recovery of polyhydroxyalkanoates from microbial cells. With a separation technology based on sequential dissolution of no-PHB cell mass in aqueous solutions, the cell mass separated from the PHB-granules is decomposed and hydrolyzed into small molecule hydrolysates that can be assimilated by microbial cells as nutrients and/or carbon source. A type of biomass hydrolysates generated from continuing treatment in acid and base solutions exhibits the best nutrient value for cell growth and PHA formation. The acid-base hydrolysates contains two major water-soluble components derived from the cell proteins and lipids, respectively. When PHB-producing cells are fed with the hydrolysates in a glucose mineral solution, the cells grow faster and form more biopolyester in comparison with the controls that do not contain the hydrolysates. The glucose-based yields of cell mass and PHA bioplastics are significantly improved. SDS is an efficient surfactant to remove the small amount of hydrophobic residues for high PHB purity, but also a potential inhibitor to microbial PHA formation. When the amount of surfactant is less than $20 \%$ of an acid-base biomass hydrolysates, its negative effect is overwhelmed by the nutritional value of hydrolysates. Under these conditions, it is highly possible to reuse most of the residual biomass discharged from PHB recovery in the next microbial PHB fermentation. It therefore eliminates a waste stream from bioplastics production and saves the nutrients with improved PHA productivity and yield.

\section{Author details}

Jian Yu, Michael Porter and Matt Jaremko

Hawaii Natural Energy Institute, University of Hawaii at Manoa, Honolulu, Hawaii, USA

\section{Acknowledgement}

The authors acknowledge a support from Bio-On to this work. MP and MJ are graduate students of Molecular Bioscience \& Bioengineering at UHM.

\section{References}

[1] Shuler ML, Kargi F (1992) Bioprocess Engineering: Basic Concepts. New Jersey: Prentice-Hall Inc. pp. 48-50. 
[2] Steinbuchel A, Valentin HE (1995) Diversity of bacterial polyhydroxyalkanoic acids. FEMS Microbiol. Lett. 128:219-228.

[3] Lenz RW, Marchessault RH (2005) Bacterial polyesters: biosynthesis, biodegradable plastics and biotechnology. Biomacromolecules 6:1-8.

[4] Yu J (2006) Microbial production of bioplastics from renewable resources. In: Yang ST, editor. Bioprocessing of value added products from renewable resources. Amsterdam: Elsevier. pp. 585-610.

[5] Solaiman DKY, Ashby RD, Foglia TA, Marmer WN (2006) Conversion of agricultural feedstock and coproducts into poly(hydroxyalkanoates). Appl. Microbiol. Biotechnol. 71:783-789.

[6] Wu Q, Huang H, Hu G, Chen J, Ho KP, Chen GQ (2001) Production of poly-3hydroxybutyrae by Bacillus sp. JMa5 cultivated in molasses media. Antonie van Leeuwenhoek 80:111-118.

[7] Park SJ, Park JP, Lee SY (2002) Production of poly(3-hydroxybutyrate) from whey by fed-batch culture of recombinant Escherichia coli in a pilot-scale fermenter. Biotechnol. Lett. 24:185-189.

[8] Madden LA, Anderson AJ, Asrar J (1998) Synthesis and characterization of poly (3hydroxybutyrate) and poly(3-hydrybutyrate-co-3-hydroxyvalerate) polymer mixtures produced in high-density fed-batch cultures of Ralstonia eutropha. Macromolecules 31:5660-5667.

[9] Full TD, Jung DO, Madigan MT (2006) Production of poly- $\beta$-hydroxyalkanoates from soy molasses oligosaccharides by new, rapidly growing Bacillus species. Lett. Appl. Microbiol. 43:377-384.

[10] Tsuge T (2002) Metabolic improvements and use of inexpensive carbon sources in microbial production of polyhydroxyalkanoates. J. Biosci. Bioeng. 94:579-584.

[11] Zhang H, Obias V, Gonyer K, Dennis D (1994) Production of polyhydroxyalkanoates in sucrose-utilizing recombinant Esherichia coli and Klebsiella strains. Appl. Environ. Microbiol. 60:1198-1205.

[12] Acquel N, Lo CW, Wei YU, Wu HS, Wang SS (2008) Isolation and purification of bacterial poly(3-hydroxyalkaoates). Biochem. Eng. J. 39:15-27.

[13] Brandl H, Gross RA, Lenz RW, Fuller RC (1990). Plastics from bacteria and for bacteria: Poly( $\beta$-hydroxyalkanoates) as natural, biocompatible, and biodegradable polyesters. Adv. Biochem. Eng. Biot. 41:77-93.

[14] McCool GJ, Fernandez T, Li N, Cannon MC (1996) Polyhydroxyalkanoate inclusionbody growth and proliferation in Bacillus megaterium. FEMS Microbiol. Lett. 138:41-48.

[15] Stuart ES, Tehrani A, Valentin HE, Dennis D, Lenz RW, Fuller RC (1988) Protein organization on the PHA inclusion cytoplasmic boundary. J. Biotechnol. 64:137-144.

[16] de Koning GJM, Lemstra PJ (1992) The amorphous state of bacterial poly[(R)-3hydroxyalkanoate] in vivo. Polymer 33:3292-3294.

[17] Gorenflo V, Schmack G, Vogel R, Steinbuchel A (2001) Development of a process for the biotechnological large-scale production of 4-hydroxyvalerate-containing polyesters and characterization of their physical and mechanical properties. Biomacromolecules 2: 45-57. 
[18] Fiorese ML, Freitas F, Pais J, Ramos AM, de Aragao GMF, Reis MAM (2009) Recovery of polyhydroxybutyrate (PHB) from Cuprivavidus necator biomass by solvent extraction with 1,2-propylene carbonate. Eng. Life Sci. 9:454-461.

[19] Kapritchkoff FM, Viotti AP, Alli RCP, Succolo M, Pradella JGC, Maiorano AE, Miranda EA, Bonomi A (2006) Enzymatic recovery and purification of polyhydroxybutyrate produced by Ralstonia eutropha. J. Biotechnol. 122:453-462.

[20] Yu J, Chen L (2006). Cost effective recovery and purification of polyhydroxyalkanoates by selective dissolution of cell mass. Biotechnol. Progr. 22:547-553.

[21] Yu J, Plackett D, Chen LXL (2005). Kinetics and mechanism of the monomeric products from abiotic hydrolysis of poly[(R)-3-hydroxybutyrate] under acidic and alkaline conditions. Polym. Degrad. Stabil. 89:289-299.

[22] Yu, J (2009). Recovery and purification of polyhydroxyalkanoates from PHA-containing cell mass. US Patent 7,514,525.

[23] Bradford M (1976) A rapid and sensitive method for the quantization of microgram quantities of protein utilizing the principle of protein-dye binding. Anal. Biochem. 72:248-254.

[24] Hesselmann RPX, Fleischmann T, Hany R, Zehnder AJB (1999) Determination of polyhydroxyalkanoates in activated sludge by ion chromatographic and enzymatic methods. J. Microbiol. Methods 35:111-119.

[25] Chittur KK (1998). FTIR/ATR for protein adsorption to biomaterial surfaces. Biomaterials 19:357-369.

[26] Kansiz M, Billman-Jacobe H, McNaughton D (2000) Quantitative determination of the biodegradable polymer poly( $\beta$-hydroxybutyrate) in a recombinant Escherichia coli strain by use of mid-infrared spectroscopy and multivariative statistics. Appl. Environ. Microbiol. 66:3415-3420.

[27] Bloembergen S, Holden DA, Hamer GK, Bluhm TL, Marchessault RM (1986). Studies of composition and crystallinity of bacterial poly( $\beta$-hydroxybutyrate-co- $\beta$ hydroxyvalerate). Macromolecules 19:2865-2871.

[28] Barham PJ, Keller A, Otun EL, Holmes PA (1984) Crystallization and morphology of a bacterial thermoplastic - Poly-3-hydroxybutyrate. J. Mater Sci. 19:2781-2794.

[29] Kim BS, Lee SC, Lee SY, Chang HN, Chang YK, Woo SI (1994). Production of poly(3hydroxybutyraic acid) by fed-batch culture of Alcaligenes eutrophus with glucose concentration control. Biotech. Bioeng. 892-898.

[30] Chen Y, Xu Q, Yang H, Gu G (2001). Effects of cell fermentation time and biomass drying strategies on the recovery of poly-3-hydroxyalkanoates from Alcaligenes eutrophus using a surfactant-chelate aqueous system. Process Biochem. 36:773-779.

[31] Strazzullo G, Gambacorta A, Vella FM, Immirzi B, Romano I, Calandrelli V, Nicolaus B, Lama L (2008). Chemical-physical characterization of polyhydroxyalkanoates recovery by means of a simplified method from cultures of Halomonas campaniensis. World J. Microb. Biot. 24:1513-1519. 